\title{
The Prudent Village: Risk Pooling Institutions in Medieval English Agriculture
}

\section{GARY RICHARDSON}

The prudent peasant mitigated the risk of crop failures by scattering his arable land throughout his village, Deirdre McCloskey argued, because alternative risksharing institutions did not exist. But, alternatives did exist, this essay concludes. Medieval English peasants formed two types of farmers' cooperatives. Fraternities protected members from the perils of everyday life. Customary poor laws redistributed resources towards villagers beset by bad luck. In both institutions, the expectation of reciprocation motivated farmers with surpluses to aid neighbors with shortages.

$\mathrm{D}$ eirdre McCloskey's theory of the prudent peasant has three tenets. ${ }^{1}$ Scattering farm fields reduced the variance of crop yields and thus the risk of starvation. Scattering farm fields reduced average crop yields and thus peasants' incomes. Scattering farm fields was the only way in which medieval English peasants mitigated risk. Translating the tenets into terms of portfolio theory forms the foundation of McCloskey's model. The risk to each farmer as measured by the variance of total output was reduced by diversifying holdings among many small plots facing different weather, weed, water, rodent, insect, and soil conditions. If one plot did poorly and another did well, a farmer could still harvest enough grain to survive from all of his plots put together. However, diversification was expensive. Scattered holdings yielded 10 percent less grain than their consolidated counterparts. So, scattering entailed an exchange of return for risk. The prudent peasant chose to scatter his farm fields to protect himself and his family from idiosyncratic agricultural shocks because better alternatives did not exist. Peasants had no better way of protecting themselves from idiosyncratic agricultural shocks.

The Journal of Economic History, Vol. 65, No. 2 (June 2005). (C) The Economic History Association. All rights reserved. ISSN 0022-0507.

Gary Richardson is Assistant Professor, Department of Economics, University of California at Irvine, 3151 Social Science Plaza, Irvine, CA 92697-5100. E-mail: garyr@uci.edu

I thank seminar participants at UCB, UCLA, UCI, and USC, the editors of this JOURNAL, and several anonymous referees for comments that improved all aspects of this essay. I thank the All-UC Group in Economic History, the Social Science Research Council, and UC Berkeley's Department of Demography for financial support. Doris Sum provided exceptional research assistance.

${ }^{1}$ For a recent rendition of McCloskey's theory, see McCloskey, "Prudent Peasant." The original version appears in McCloskey, "English Open Fields." 
Peasants lacked access to cheap relief. Medieval men and women, for example, neither practiced charity nor pooled risk.

McCloskey's conclusion piqued Miles Kimball's curiosity. Modern insurance institutions may not have existed, but what about informal arrangements? A system of consumption loans among farmers could have performed some or all of the functions that formal institutions failed to perform. Those arrangements could have arisen in the guise of the extended family, a fraternal order, or a group of fast friends. Kimball labeled all such arrangements "farmers' cooperatives," and modeled those cooperatives as repeated games. Kimball calibrated the models with McCloskey's data on medieval crop yields and demonstrated that farmers' cooperatives should have existed in medieval English villages. If utility discount rates in the Middle Ages were anything like they are now-if medieval peasants were perhaps a trifle more impatient because they were poorer and also discounted the future a few percent more per year because of their higher adult mortality rates then

farmers' cooperatives could have provided a substantial amount of insurance even among farmers with a degree of risk aversion that would not justify scattering. Farmers with higher levels of risk aversion could have formed selfenforcing cooperatives involving substantial sharing of output even at very high discount rates. These cooperatives could not enforce full sharing in very bad times, but in normal times would provide insurance at a much lower cost than scattering of plots. ${ }^{2}$

Kimball surmises, therefore, that farmers' cooperatives did in fact exist in medieval English villages.

Kimball's conjecture seems sensible. Cooperation pervaded medieval English villages. The cultivation of open fields was a collective enterprise. Teamwork occurred in planting, harvesting, and husbandry. Peasants pooled oxen to form plough teams and fallow land to form pastures. Village councils regulated the rhythms of rural life and the agricultural cycle of planting, harvesting, and fallowing. Village residents gathered regularly - every three weeks in many places - at manorial courts that enforced those regulations. Residents also gathered at parish churches, where their collective endeavors supported local priests. In all of these areas, repeated interaction, the anticipation of reciprocation, and the fear of punishment sustained cooperative arrangements among self-interested peasants. Such mechanisms may have worked for risk as well.

\footnotetext{
${ }^{2}$ Kimball, "Farmers' Cooperatives,” pp. 230-31.
} 
This essay demonstrates that they did. It corroborates Kimball's conjecture by describing two institutions that fit Kimball's definition of farmers' cooperatives. Both institutions pooled risk among village residents. The first was the fraternity. ${ }^{3}$ These voluntary associations of rural residents provided a spectrum of secular and spiritual services. Protecting members from the perils of everyday life and helping members escape purgatory were their principal tasks. The second was the customary poor law. Manorial courts enforced these rules that redistributed resources towards villagers beset by bad luck. The existence of these two institutions has clear implications. Kimball's conjecture that peasants formed farmers' cooperatives is correct. McCloskey's presumption that peasants did not is inconsistent with the evidence. The conclusion of this essay elucidates the logic underlying those implications, after the next four sections have presented the essential evidence.

\section{SOURCES OF EVIDENCE}

Evidence on fraternities is abundant and unambiguous. Evidence on customary poor laws is scarce and straightforward. The former consists of thousands of observations compiled into large databases. The latter consists of scores of observations from scattered places. This section describes those sources, their reliability, and the nature of the inferences that can be drawn from them.

For fraternities, three principal sources of information exist. These include a cross section from the year 1388, which contains hundreds of observations from around the nation, and panels for the counties of Cambridge and York spanning the years 1350 to 1550 . The cross section comes from the corporate census from the reign of Richard II. ${ }^{4}$ The census provides more information about the structure and activities of fraternities than any other source. Two hundred thirty-four census returns survive from hamlets, villages, and other rural settlements. The re-

\footnotetext{
${ }^{3}$ A note on nomenclature. Historians know fraternities by many names including confraternities, cooperatives, guilds (parish, religious, social, and village), and societies (benevolent, burial, and friendly). This essay, like most others, treats those terms as synonyms with one distinction. Throughout these pages, the term guild refers to a voluntary association of individuals pursuing their collective interests. The term fraternity refers to a guild operating in rural environs.

${ }^{4}$ The surviving returns reside in the Public Record Office (C47/38-46). Tolman Smith published most of the returns written in English and summarized 50 returns written in Latin and French, see Smith, English Gilds. H. F. Westlake published a table summarizing the religious and risk-sharing aspects of most returns, see Westlake, Parish Gilds.
} 
turns provide information on the purpose, organization, finances, functions, and membership of fraternities. The largest limitation of the census is that it represents a single date. It contains little information about the distribution of fraternities through space and time.

The database constructed by Virginia Bainbridge for her study, Gilds in the Medieval Countryside: Social and Religious Change in Cambridgeshire c.1350-1558, fills those spatial and chronological lacunae. Bainbridge examined a wide array of manuscripts at the Public Record Office, all extant fraternity records and churchwarden's accounts at the Cambridge County Record Office, substantial sets of documents at the British Library and Cambridge University, and a broad spectrum of published primary sources. Her efforts uncovered evidence of 350 fraternities in Cambridgeshire at different times and places. Nearly half of the fraternities appear in the data panel only once. The others appear multiple times. ${ }^{5}$

David Crouch constructed a similar database for his study, Piety, Fraternity, and Power: Religious Gilds in Late Medieval Yorkshire 1389-1574. Crouch canvassed the record offices of Beverly, Kingston Upon Hull, Humberside, and York as well as the collections of the Borthwick Institute, the Merchant Adventurers' Archive, the British Library, and the Public Record Office. Crouch also scoured a vast array of published primary sources. His efforts reveal the existence of 388 guilds. One hundred thirty-four appear in a single bequest, and in most cases, that is the only proof of their existence. The rest appear at multiple points in time. ${ }^{6}$

Regretfully, the sampling processes that generated these data sets are opaque. Analyzing them requires many assumptions. Even so, straightforward methods and modern econometric techniques yield reasonably robust results.

Evidence concerning customary poor laws is less extensive. Manor court rolls are the principal source. Courts met regularly in medieval English villages, typically once every three weeks or once a month. Laws required adult-male residents to attend these meetings unless possessing an appropriate excuse. Manorial courts enforced a complex array of customary laws, rules regarding landholding, conventions concerning collective cultivation of the open fields, and social mores and norms. Scholars have translated and published scores of manor court rolls. However, no comprehensive database exists. This essay examines

\footnotetext{
${ }^{5}$ Bainbridge, Gilds.

${ }^{6}$ Crouch, Piety and Gazetteer.
} 
the most widely cited collections of documents and the historical literature on the topic. ${ }^{7}$

\section{FUNCTIONS OF FRATERNITIES}

Fraternities fulfilled several functions for medieval men and women, including the provision of sociability, solidarity, and ceremony. Two functions of fraternities pertain particularly to Kimball's concept of farmers' cooperatives. The first was helping members beset by bad luck. The second was helping members save their souls. These twin tasks complemented each other, and the internal organization of fraternities facilitated both.

Fraternities guaranteed aid in clear, unequivocal terms. An example comes from Kyllyngholm, a village "of lesser importance" in Lincolnshire, whose residents established a fraternity in 1310 with the following ordinances

If a brother or sister dies, four brethren shall offer a penny, and each sister shall give a halfpenny loaf. If a brother or sister is unlucky enough to lose a beast worth half a mark, every brother and every sister shall give a halfpenny towards getting another beast. If the house of any brother or sister is burnt by mishap, every brother and every sister shall give a halfpenny towards a new house. Moreover, if the house of any brother or sister is broken into by robbers, and goods carried off worth half a mark, every brother and every sister shall give half a penny to help him. ${ }^{8}$

Additional examples come from the village of Oxborough in southwestern Norfolk. There, the Fraternity of Holy Trinity promised 15 shillings 6 pence per year to those impoverished by accident, illness, fire, flood, pestilence, or other peril. The Fraternity of St. Peter promised similar help in similar circumstances, although a smudge on its census return conceals the monetary amount. ${ }^{9}$ The Fraternities of St. John the Baptist and Corpus Christi promised 3.5 pence per week to members who fell into poverty.

\footnotetext{
${ }^{7}$ These sources include Ault, Open-Field Farming; Britton, Community of the Vill; DeWindt, Land and Community and Court Rolls; Fisher and Jurica, Documents; Hanawalt, Ties; Hunt, Medieval Customs; Page, "Customary Poor Law"; Raftis, "Social Structures"; Tierney, Medieval Poor Law; and Titow, English Rural Society. Additional information on village fraternities also appears in those sources and in Duparc, "Confraternities"; Hanawalt, "Keepers"; Jones, "English Religious Brotherhoods"; Mattingley, "Medieval Parish Guilds"; Palmer, "Village Gilds"; and Rosser, "Communities."

${ }^{8}$ Smith, English Gilds, pp. 185-86.

${ }^{9}$ Smith, English Gilds, pp. 121-22; and Westlake, Parish Gilds, pp. 207-08.
} 
TABLE 1

BENEVOLENT ACTIVITIES OF 234 RURAL FRATERNITIES IN THE CORPORATE CENSUS OF 1388

\begin{tabular}{lcc}
\hline \hline & Number & Percent \\
\hline Assistance for members in need & 34 & 14.5 \\
Weekly cash stipend & 18 & - \\
Other cash stipend & 5 & - \\
Aid in-kind or unspecified & 11 & - \\
Charity for all individuals & 33 & 26.9 \\
Total & 63 &
\end{tabular}

Note: Four members in need and provided charity to individuals outside the organization. Sources: Public Record Office C/47/38-46. Translations by Toulmin Smith 1870 and H. F. Westlake 1919 and G. Richardson. Tabulation by G. Richardson fraternities aided.

Fraternities helped needy members in many ways. Some provided inkind aid. Others issued loans. Most distributed stipends. Weekly stipends ranged from three to 12 pence per week. The average for guilds in the census of Richard II was five and one-half pence per week, an amount that provided a family "with sufficient calories, but little else," and an individual with "a decent but sparse living with meat and ale to go with [their] bread." "10 The minimum was three pence per week, an amount that for a family financed an austere existence of peas and beans.

The census contains many returns possessing such provisions. Table 1 displays summary statistics. Column 1 indicates the number of census returns containing clauses of particular types. Column 2 indicates the percentage. Thirty-four fraternities assisted members in need. Eighteen of those provided weekly stipends of three pence ( 5 fraternities), three and a half pence (2), four pence (2), six pence (1), seven pence (3), eight pence (2), 12 pence (1), and one farthing from each member each week (2). Five fraternities provided cash stipends in other forms such as annual amounts or amounts per loss. Eleven fraternities provided aid in-kind or in unspecified terms. Almost all of these fraternities promised to extend help whenever it was needed. Common phrasing promised aid to members "in need," "in poverty," "in indigence," "in sickness," and in "old age." A small fraction specified help in particularly circumstances such as losses of houses, chattel, and cattle due to hazards of nature or man such as fire, flood, and theft. An additional 29 fraternities vowed to help indigent individuals, without specifying that these individuals had to be members of the organization. Seven fra-

\footnotetext{
${ }^{10}$ Quote from Dyer, Standards of Living, p. 253. For real wages and the cost of living, see Dyer, Standards of Living, pp. 215-7, 222-23, 226-29.
} 
ternities pledged "to assist the poor and sick of the town." Four fraternities promised "to relieve the deserving poor and sick." The remainder promised assistance of various types, such as providing alms to the poor, or food - often leftovers - to the hungry, or small amounts of cash to those who requested it.

The total number of fraternities describing benevolent activities, 63, was more than one quarter of those replying to the census. That number seems surprisingly high. A substantial share of the census returns survive only as fragments. The vast majority of the remainder contain cursory information such as a fraternity's location, patron saint, and religious rituals but little else. That pattern exists for an obvious reason. Parliament promised to preserve organizations dedicated to divine worship. ${ }^{11}$ So, fraternities had an incentive to describe and perhaps even exaggerate religious activities. Only one in three fraternities described secular activities in detail. Of those, most mentioned the sharing of risk. Fraternities had a disincentive to describe such provisions. Parliament sought new sources of revenue. Helping members in need required fraternities to collect and redistribute funds. Organizations with the ability to raise revenue were lucrative targets of taxation. The resources that they could command tempted government to commandeer their wealth. Thus, the number of fraternities describing risk-sharing activities should be biased downwards, and the number of fraternities describing religious rituals should be biased upwards.

Fraternities' second principal function was pursuing spiritual goals. The principal pious objective was the salvation of the soul. Christian doctrine proclaimed that the way people lived their lives determined the fates of their souls after death. The saintly entered Heaven. The infamous who did not confess and repent before death went to Hell. The preponderance of the population spent a period in Purgatory. ${ }^{12}$ Praying devoutly, sponsoring masses, and giving alms were three of the most effective methods of redeeming one's soul. Those works of atonement could be performed by the penitent individual on his own or by someone else on her behalf. The more pious the person, the more salutary the supplication. Particularly beneficial were prayers of priests and persons who knew the deceased well, such as relatives, friends, and neighbors.

To help members enter heaven, all fraternities performed actions on members' behalf, usually after their deaths. Postmortem services began with funerals and burials and continued into perpetuity. All fraternities

\footnotetext{
${ }^{11}$ Tuck, "Cambridge Parliament," p. 257.

${ }^{12}$ Harper-Bill, Pre-Reformation Church, p. 67.
} 
prayed for the souls of members living and dead. Many fraternities kept a roll of names to refresh memories. Some hired priests to pray for the souls of those on their rolls.

Church doctrine had another important effect. It synergized fraternities' twin tasks. The theme of charitable obligation appeared throughout medieval religion. Plays, such as Everyman, taught audiences that Heaven awaited those who gave alms to the poor and did good deeds, while Hell awaited those who did not. Biblical pageants performed on religious holidays told the same tale. ${ }^{13}$ Religious writers proclaimed that spiritual welfare in the world to come depended on good deeds done in the present day. ${ }^{14}$ Parish priests lectured parishioners about their charitable obligations. Priests learned to do this from pastoral manuals. A manual typical of the teaching aids available in the eleventh century set forth the duties of Christian men and women. It contained eight articles, four of which related to works of mercy: "Keep charity always in thy heart"; "Relieve the poor"; "Visit the sick"; and "Bury the dead."

Similarly, a twelfth-century manuscript entitled A Model Parish Priest described the objective of a sermon: to teach parishioners "to pray devoutly in the church, to pay their tithes truly, to walk about and visit poor men, [and] to spend their goods in such a way as is pleasant to God and a comfort to the poor." $" 16$

These religious edicts ensured fraternity members fulfilled charitable obligations. To pass through purgatory, members had to atone for sins by purchasing indulgences, paying for prayers, praying for God's grace, and helping the downtrodden. Helping a fraternity brother whose fields had failed was one way to solicit God's favor. Watching him starve while your fields flourished would incur God's wrath. In other words, the desire to go to Heaven ensured that fraternity members with surpluses helped fraternity members suffering shortages.

Another religious belief solidified the nexus of religion and risk. Charitable obligations emphasized the deserving poor. ${ }^{17}$ The most deserving were pious and industrious peasants who suffered runs of bad luck. ${ }^{18}$ This bias towards the deserving poor was enshrined in the charters of many charitable institutions, which often had charters requiring

\footnotetext{
${ }^{13}$ Cawley, Everyman, pp. xiii-xxiii, 195-225.

${ }^{14}$ See for example, Saint Gregory's sermon Pastoral Care, Saint Caesarius's collection of Homilies, and the essays of Hincmar of Rhiems in Mollat, Poor, pp. 38-39, 45, 46-47.

${ }^{15}$ Mollat, Poor, p. 89.

${ }^{16}$ McLaughlin and Ross, Portable Medieval Reader, p. 75.

${ }^{17}$ Bainbridge, Gilds, p. 107; Rubin, Charity, pp. 72-73; and Tierney, Medieval Poor Law, p. 59.

${ }^{18}$ Harvey, Living, pp. 17-22.
} 
them to "alleviate the suffering of all the unfortunate, and especially of "paupers who from a fortunate state had fallen into indigence." 19 This bias also appeared in popular literature, such as William Langland's Piers Plowman, in which the peasant protagonist learns the way to obtain the grace of god was to help "anyone who's come down in the world through no fault of his own but sheer bad luck, or has suffered at the hands of some group of scoundrels" while forcing able-bodied beggars "to earn their bread by working.," 20

Fraternities served as a mechanism for screening the deserving and undeserving poor. To do this, some fraternities required members seeking charitable assistance to make a formal request to the organization, and those petitioners received aid only if the officers and a majority of the brethren approved their request. Other fraternities rigorously applied "means tests" to discriminate between deserving and undeserving cases. Most fraternities ensured members did not become addicted to assistance by adopting the ethos that "aid was a temporary solution to sudden calamity or misfortune, intended either to enable the brethren to recover their former status shortly, or to die with some dignity." ${ }^{21}$ Of course, by ensuring that individuals met regularly, fraternities enabled members to know who among them deserved help and who did not.

Fraternities also adopted ordinances that mitigated the collectiveaction afflictions of free riding, moral hazard, and adverse selection. To discourage free riding, fraternities punished members who did not pay their dues, refused to serve as officers, missed meetings, skipped funerals, and in general, failed to pull their own weight. To mitigate moral hazard, fraternities helped only those who fell into poverty "not of his own rashness or negligence" ... "through mishap, without any selfguilt" . . . "by fire, murrain, robbery, or by any other mishap — so that such loss come not through his own lust, or gluttony, or dice-play, or other folly" .. . "by mishap or sickness, so that it is not through plunder by harlots, or through any other bad way of life." 22 To protect against adverse selection, fraternities restricted entry to people from one parish, relatives of founders, and exceptionally pious persons. Fraternities required applicants to "be of good repute," to be "sufficiently good, pious, and devoted," to seek recommendations from current members, to receive approval from the alderman, and to wait for several years after

\footnotetext{
${ }^{19}$ Mollat, Poor, p. 157.

${ }^{20}$ Langland, Piers Plowman, pp. 70-71.

${ }^{21}$ Bainbridge, Gilds, p. 115.

${ }^{22}$ Smith, English Gilds, pp. 166, 267, 269-70; and Westlake, Parish Gilds, p. 267.
} 
admission before becoming eligible for benefits. ${ }^{23}$ Those protections prevented unscrupulous individuals from advancing their own interests at the fraternity's expense. Those mechanisms also helped fraternities regulate the size of their organizations and screen out applicants of modest means.

Fraternities typically contained many prosperous peasants and few men lacking land or other sources of income. Prosperous members were important. They increased the ability of the organization to support brethren in need and reduced the probability that individuals would need aid. Size was also important. Some fraternities had a few dozen members from a single village. Others had hundreds of members from miles around. Average membership appears to have been between a few score and a hundred or so. That high average ensured that idiosyncratic shocks would not beset all members at the same time.

Fraternities possessed another common feature. They possessed procedures for making and implementing collective decisions. Most fraternities held quarterly meetings where members amended rules and yearly elections where members chose officers. Small fraternities usually selected a single warden and a group of stockholders. Large fraternities often established hierarchies. At the top sat an alderman, who directed the fraternity's day-to-day affairs and supervised subordinate officers. Next came stewards, who handled fraternity finances. Then came deans, who monitored members' behavior and organized fraternity events. At the bottom were clerks, who kept records. "In general, aldermen and officers acted with some degree of consensus from the membership. ..." ${ }^{24}$ In other words, officers implemented policies approved by members.

Fraternities also possessed means of raising and managing money. Most fraternities collected periodic dues. Many imposed entrance fees. A few required dying members to bequeath cash, corn, animals, or land. Some fraternities collected contributions in cash. Others accepted grain. The Fraternity of St. Nicholas from Worton in Oxfordshire required every member to contribute one bushel of grain each year to pay for religious services. The Fraternity of Corpus Christi from Alvingham in Lincolnshire required each member to donate one quarter of barley when the organization was established. ${ }^{25}$ Assets including grain, animals, and strips in the common fields were accumulated by some fraternities such as the Fraternity of Our Lady from Eyam, which

\footnotetext{
${ }^{23}$ Smith, English Gilds, pp. 74, 139; and Westlake, Parish Gilds, pp. 163, 175.

${ }^{24}$ Bainbridge, Gilds, pp. 137-42.

${ }^{25}$ A quarter of grain equaled eight bushels.
} 
was "endowed chiefly with oxen let out to diverse persons"; the Fraternity of the Blessed Virgin Mary and the Holy Trinity from Hatherlegh, whose goods included " 13 oxen, 7 cows, 5 bullocks, and 6 heifers"; the Fraternity of Our Lady from Baslow in Derbyshire, which had "oxen for hire and some lands"; and the Fraternities of St. John the Baptist and St. Peter from Oxborough in Norfolk whose goods included "20 quarters of barley" and "5 quarters of barley" valued at 20 pence a quarter respectively. ${ }^{26}$ Other fraternities, usually those serving the poorer segments of the population, collected funds only when they needed cash to achieve an immediate objective, such as supporting an indigent member. A few fraternities redistributed funds directly from well off to worse off members. In several of these guilds, needy members received ". . . day by day, a penny from the [brothers] and [sisters] of the gild, in the order in which their names stand on the register of their admission . . . each brother or sister giving in turn, out of his own means.",27

In sum, fraternities fulfilled two principle tasks. One was helping members in need. The other was helping members enter heaven. These functions complemented each other. Religious beliefs encouraged members to fulfill charitable obligations. Charitable acts shortened stays in purgatory and accelerated entrance into heaven. Fraternities' structure enabled them to accomplish both tasks. Ordinances and officers allowed fraternities to make and implement collective decisions. Rules against free riding, moral hazard, and adverse selection prevented unscrupulous individuals from taking advantage of the organization.

\section{NUMBER OF FRATERNITIES}

The previous section tilts the scales of scholarship in favor of Kimball's conjecture. Kimball argues that farmers' cooperatives could (and should) have existed. Evidence of farmers' cooperatives indeed exists. Thus, Kimball's conjecture is confirmed. The question remains, however: how correct was Kimball? How widespread were fraternities? Were they rare? Were they common?

Ubiquitous is the answer supplied by the experts on the issue. Three historians lead the field. Gervase Rosser writes that the number of fraternities "alone commands attention."

\footnotetext{
${ }^{26}$ The diverse examples in this paragraph come from Westlake, Parish Gilds, pp. 33, 64, 147, $149,150,152,154,185,188,191,208$, and 235.

${ }^{27}$ Smith, English Gilds, p. 179.
} 
fifteenth-century England probably contained 30,000 guilds. This total would represent, on average, three associations in each of the 8,000 or 9,000 parishes. $^{28}$

\section{Virginia Bainbridge writes that}

gilds were far more than religious organizations. Their functions covered a broad spectrum of both religious and secular activities. . . If members fell on hard times, or became impoverished at the end of their lives, charity was given out of the common funds, and their funeral expenses were paid. ${ }^{29}$ [And that by 1547] there had been gild activity in nearly every town and village in Cambridgeshire in the preceding two hundred years. ${ }^{30}$

\section{David Crouch writes}

That gilds were proliferating throughout the country in the late fourteenthcentury seems certain . . . gilds were discovered in ninety-five locations [in Yorkshire] where poll tax populations were less than 220. This represents seventy-two per cent of all the places where gilds were identified. Such a high proportion might suggest that there were many more gilds in places with populations at all levels than have come to light. Indeed, bearing in mind the low probability of gild members making bequests to their fraternities, it tends to support the contention that gilds were an almost universal phenomenon. . . . gilds were probably present in most late medieval communities. ${ }^{31}$

The experts are unanimous. Fraternities existed in most villages in latemedieval England.

The evidence examined in this section corroborates that conclusion. Bainbridge's dataset is the place to start. She found evidence of 342 fraternities operating in 73 percent (125 of 172) of Cambridgeshire's towns and villages between 1350 and 1558. The implications of these facts hinge on estimates of fraternities' longevity. Bainbridge's dataset allows the calculation of two independent estimates. The first is the survival rate of fraternities from 1388 to 1547. In 1388, 60 Cambridgeshire fraternities replied to the corporate census. In 1547, 17 ( 28 percent) of those fraternities remained. The survival rate of 28 percent can be converted to a lower-bound life expectancy with two assumptions. First, the organizations that survived from 1388 to 1547 existed for 158 years. The data indicate, of course, that they operated for at least that long and probably longer. Second, the fraternities that did not survive until 1547 operated for only one day. Of course, the data once again indicate that

\footnotetext{
${ }^{28}$ Rosser, "Going to the Feast," pp. 430-31.

${ }^{29}$ Bainbridge, Gilds, p. 20.

${ }^{30}$ Bainbridge, Gilds, p. 33.

${ }^{31}$ Crouch, Piety, pp. 43, 54-55, 65.
} 
they operated for at least that long and probably much longer. Then, the average fraternity operated for 44 years and 3 months. The second estimate of fraternities' longevity can be calculated from fraternities' first and final dates in Bainbridge's dataset. According to Bainbridge, 168 fraternities are known to have existed at a single date; 107 fraternities are known to have existed at two points in time less than 50 years apart; 35 fraternities are known to have existed at two points in time from 50 to 100 years apart; and 37 fraternities are known to have existed at two points in time from 100 to 200 years apart. Assuming the average fraternity survived to the midpoint of the relevant interval implies that the average fraternity survived for 43.37 years.

That estimate facilitates the comparison of data about fraternities with data about communities. This comparison answers the question: how many fraternities existed in a typical village at any point in time? In Bainbridge's data set, 342 fraternities operated for an average of 43.37 years (the lower longevity estimate above). According to historical geographers, 172 towns and villages existed in Cambridgeshire during the two centuries separating the Black Death and Reformation. This means that four days of data regarding fraternities exists for every ten days of data regarding towns and villages. Another way of putting this is that four-tenths of a fraternity existed in the typical village at any point in time. That estimate is a lower bound. It does not account for the disappearance of documents from fraternities that existed in the past.

These historical records are, undoubtedly, a small fraction of those that once existed. Documents from thousands of fraternities disappeared during the Reformation, when the Tudor regime suppressed and looted all organizations with religious overtones. Fraternities hoping to conceal funds and to hide affiliations with superstitious practices of the past destroyed many of their own records. Auditors dispatched by the royal government recorded the information that they sought (typically the sum of an association's expropriable wealth), retained documents that corroborated their conclusions, and discarded everything else. Documents also disappeared during the five centuries following the Reformation. Fraternity records lacked legal, financial, and political significance. Retaining them did not prove ownership of property or the possession of legal right. So, they were seldom saved.

Once the disappearance of documents is accounted for, the estimate rises significantly. A simple formula can correct for the disappearance of documents during the last six centuries. The formula is $M=N / S$. The letter $M$ denotes the number of fraternities that existed during the Middle Ages. $M$ is unknown. It is what we want to determine. The letter $N$ denotes the number of fraternities for which evidence survives today. 
The letter $S$ denotes the document survival rate. It is also unknown. No direct evidence of it exists. Historians gauge it by argument and analogy. It can also be estimated.

There is a natural way to estimate the survival rate of documents, particularly for databases, such as Bainbridge's, based largely on the census of corporations. Identify categories whose numbers are well known from historical sources. Count the number that appears in the census. Compare those values. The ratio reveals the percentage of the category for which census returns survive. Analogy suggests similar ratios should hold for similar categories. Toulmin Smith, the scholar who discovered the surviving census returns stuffed into a leather sack in the basement of the Chancery, advocated this approach. ${ }^{32}$

The number of writs that announced the census to the public is well known. England had 33 sheriffs. Each received two writs. The chancery ordered sheriffs to return the original writs with annotations explaining how they notified fraternities of the census. Of the 66 writs dispatched to England's 33 sheriffs, 22 survive in the Public Record Office today. ${ }^{33}$ Analogy suggests similar proportions of rural fraternities appear in the returns at the Public Record Office.

The number of craft guilds in London is also relatively well known. The exact figure for the date of the census does not exist, but figures exist for dates near enough to provide useful approximations. In the ninth year of the reign of Henry V (1420), the brewers' guild listed the 111 occupations then in London, suggesting that 111 craft guilds existed at that time. ${ }^{34}$ The number existing in 1388 was probably close to that amount. The number rose rapidly during the decades after the Black Death as crafts became increasingly specialized. The number declined gradually during the fifteenth century as fraternities in related industries merged and consolidated. The peak appears to have been reached during the generation spanning the turn of the century. So, the number 111 is both a best guess and an upper bound. The number of fraternities that existed in 1388 was probably near that number. There is no reason to think it was substantially higher. In 1501 London city records list 47 livery companies and 22 fraternities without livery divisions, for a total of $69 .{ }^{35}$ All of these organizations claimed ancient foundations (that is,

\footnotetext{
32 Smith, English Gilds, p. 132.

33 For the fact that writs were sent to all of England's sheriffs, see Smith, English Gilds, p. 132 who cites it to the Close Rolls, 12 R.II. m. 32, in dorso. For the number of returned writs, see Smith, English Gilds, p.132.

${ }^{34}$ Unwin, Gilds, appendix A, pp. 370--71.

${ }^{35}$ Thrupp, Merchant Class, p. 42.
} 
before 1388). Historical sources confirm their claims. So, the number 69 is a lower bound. The upper and lower bounds allow us to calculate the proportion of London's craft guilds appearing in the census. Eleven census returns survive from London guilds. Thus, roughly one-in-six (15.9 percent) of the guilds that definitely existed at the time and slightly less than one-in-ten (9.9 percent) of the guilds that probably existed at the time appear in the census. Analogy suggests similar proportions of rural fraternities appear in the returns at the Public Record Office.

The analogy may not be perfect. The response rate for London's craft guilds should have been higher than the response rate for rural fraternities for three reasons. First, government knew of the existence of the London craft guilds. They operated publicly in the capital. Nonresponse would not hide them from the tax collector's eyes. In contrast, government lacked information about rural fraternities. If they did not respond, the central government might not learn of their existence. Second, for London's craft guilds, failure to respond could have had severe consequences. Most operated under the auspices of municipal authorities. A dozen or so received royal charters. Almost all possessed legal privileges. According to the writ that proclaimed the census, failure to respond voided those liberties. Rural fraternities had less to fear from the threat. Few possessed letters patent or needed special legal powers to operate effectively. The threat to revoke government grants did not frighten them. Third, for London's craft guilds, the cost of responding was low. Many Londoners could read and write. Most guilds kept written records. Members could write their organization's response, walk a few minutes, and deliver it to the Chancery. For fraternities, completing the census was an expensive and time-consuming task. Literacy was less common in the countryside. Many fraternities hired scribes to write their returns and couriers to take the response to London.

Given these caveats, it is reasonable to conclude that the survival rates of the writs that announced the census and of the returns of London guilds almost certainly overestimate the percentage of documents that survive from rural fraternities, and thus underestimate the number of fraternities that existed in the past. Plugging those three document survival rates into the formula for $M$ suggests that either 1,026, 2,151, or 3,455 fraternities existed in Cambridgeshire between the Black Death and Reformation.

Fraternities did not last forever, of course. Far fewer existed at any point in time. The typical fraternity operated for only 43.37 years. Taking that fact into account yields a formula for estimating the average number of fraternities that existed in the typical village at any point in time. The formula is 


$$
m=\frac{N \cdot A}{S \cdot Y \cdot T}
$$

where the letter $m$ indicates the average number of fraternities in the typical village during the typical year. The letters $N$ and $S$ have the same definitions as before. The letter $A$ equals average fraternity longevity. The letter $T$ equals the number of years of our study. The letter $Y$ equals the number of villages and towns in Cambridgeshire during that period. The values of the last three variables are 43.47, 200, and 172 respectively. Given this information, our estimates of document survival rates provide a range of estimates for the number of fraternities existing in the typical village on any given date. Those estimates are 1.3, 2.7, and 4.4. Those predictions can be further corrected for the disparity in size between towns and villages. Cambridgeshire had two large towns, Cambridge and Ely, each of which contained nearly 50 fraternities at their peak. Cambridgeshire also contained 18 smaller towns, in which the number of fraternities appears to have varied considerably over time, and which contained on average approximately five to ten fraternities each. Given the values for the other variables, therefore, our estimate of $m$ for the remaining villages and hamlets ranges from one-half to three fraternities each.

There is much for improving that estimate. The longevity calculations and corrections for town size are crude, as they are based on summaries of Bainbridge's data, rather than the raw data itself. The document survival rate is also awkwardly measured. All can be improved by statistically analyzing Bainbridge's original data and collecting additional evidence. Improved measures should strengthen this section's conclusions. The inferences would be difficult to weaken. Lowering the document loss rate to 57 percent would still indicate one fraternity existed at all times in every village. Lowering the document loss rate to 15 percent would still indicate that one fraternity existed at all times in every other village. Lowering the document loss rate to zero- that is asserting that we have evidence of all guilds that ever existed-would still indicate that four fraternities existed in every ten villages. With that many fraternities, a typical prosperous peasant could have joined a fraternity if he desired, because many fraternities had members from multiple villages. The historical record also contains many examples of villages with multiple fraternities. One is the village of Oxborough mentioned earlier. It contained six fraternities in the latter half of the fourteenth century. Another is the rural community of Bottisham in the hundred of Staine southeastern Cambridge, which contained seven fraternities and 
TABLE 2

FRATERNITIES IN YORKSHIRE, 1350 TO 1550: KEY STATISTICS FROM CROUCH'S DATA

\begin{tabular}{|c|c|c|c|c|c|c|c|}
\hline & \multicolumn{2}{|c|}{ Locations } & \multicolumn{3}{|c|}{ Fraternities } & \multicolumn{2}{|c|}{ Longevity (years) } \\
\hline & \multirow[b]{2}{*}{ Total } & \multirow{2}{*}{$\begin{array}{c}\text { Number } \\
\text { with } \\
\text { Fraternities }\end{array}$} & \multirow[b]{2}{*}{ Total } & \multicolumn{2}{|c|}{$\begin{array}{c}\text { With How Many } \\
\text { Observations? }\end{array}$} & \multirow[b]{2}{*}{ Average } & \multirow{2}{*}{$\begin{array}{c}\text { Standard } \\
\text { Error }\end{array}$} \\
\hline & & & & 1 & $2+$ & & \\
\hline Towns & 48 & 30 & 204 & 102 & 102 & 66.4 & 4.97 \\
\hline Villages & 1,073 & 136 & 183 & 119 & 64 & 33.5 & 4.19 \\
\hline Total & 1,121 & 166 & 387 & 221 & 166 & 53.7 & 3.66 \\
\hline
\end{tabular}

Sources: Data on fraternities are from Crouch, Piety, pp. 252-64, and Crouch Gazetteer. Data on locations are from Crouch, Piety, pp. 52-54; and Sheeran, Medieval Yorkshire Towns.

170 households in the latter half of the fourteenth century. ${ }^{36}$ So, the range of estimates seems consistent with both historical facts and Kimball's conjecture.

The difficulties of using Bainbridge's summary statistics can be overcome by analyzing Crouch's micro data. Crouch observes 387 fraternities in Yorkshire from 1389 and 1547 (see Table 2). The observations come from 190 of York's 682 parishes (27.7 percent) and 132 of the 1,121 places with poll-tax populations of 20 and above during in 1377 (11.8 percent). ${ }^{37}$ The combination of Crouch's data and equation 1 yields an estimate for the number of fraternities in the typical village at any point in time. The formula requires five pieces of information. $N$, the number of rural fraternities for which evidence survives today, is 183. $T$, the number of years for which Crouch collected data, is 158 (i.e., 1547 minus 1389). $Y$, the number of villages in Yorkshire, is 1,073 . $A$, the longevity of the average fraternity, is 33.5 years. A reasonable estimate for the survival rate of documents, $S$, is 5 percent. Thus, our best guess of the number of fraternities in the typical village in the typical year is 0.723 , or roughly three fraternities in every four villages.

Uncertainty exists about three components entering into that estimate. The first is $Y$, the number of villages. The economic topography of Yorkshire changed significantly between the reigns of Edward I (12721307) and Edward VI (1547-1553). Some villages, such as Leeds, grew into towns. Some towns, such as Skipsea, shrank into hamlets. More

\footnotetext{
${ }^{36}$ Bainbridge, Gilds, p. 132; Russell, Medieval British Population, p. 307; and Westlake, Parish Gilds, p. 182.

${ }^{37}$ For Poll Tax information see Crouch, Piety, figure 2.3, p. 53. Note the poll tax figures exclude 27 locations whose assessments were not recorded and the City of York, with its 25 parishes and 57 fraternities.
} 
than 100 villages disappeared entirely. Some were lost to enclosure. Some were lost to depopulation. Others were consumed by the sea. Throughout this period, the number of inhabited places fluctuated along a downward trajectory. The peak occurred in the early fourteenth century. The trough occurred in the late fifteenth century. Information about inhabited places is also imperfect. Data exist on the populations and wealth of inhabited places at various points in time, but our knowledge of economic topography is far from perfect. In the foregoing estimate, I use Crouch's own estimate of the number of villages in Yorkshire based on the Poll Tax of 1377, after subtracting from the data all of the fraternities operating in the towns identified by George Sheeran, a leading scholar of urbanization in medieval Yorkshire. ${ }^{38}$ To test the robustness of that method, I repeated the estimation using information on inhabited places from several other sources. The Lay Subsidy of 1334 provides the largest figure for the number of villages, because at that time, the exploitation of arable land reached the greatest extent and urbanization was limited. ${ }^{39}$ Using figures drawn from the Lay Subsidy lowers the estimated number of fraternities per village by approximately 10 percent (i.e., from 0.72 to 0.65 fraternities per village). Using figures drawn from or Beresford's data on the number of villages inhabited in the early fourteenth century, which combines information from the Lay Subsidy's with the archaeological surveys of the Deserted Medieval Village Research Group, lowers the estimate by a slightly larger amount. A geographic cross-section of Yorkshire at the beginning of the sixteenth century that I constructed from several sources - the Victoria County History, the Database of British Borough Charters, an array of topographical dictionaries, and the Lay Subsidy of 1524-yields a smaller figure for the number of villages, because at that time, the population had fallen, a great deal of land had left cultivation, and urbanization had increased. ${ }^{40}$ Using these data raises the estimate of the number of fraternities per village by approximately 5 percent.

Another way to test the robustness of my estimate is to change the unit of observation from the village to the parish. Parishes are useful analytical units, because their boundaries remained relatively stable over the period of study, and they corresponded in most case to gov-

\footnotetext{
${ }^{38}$ Crouch, Piety, pp. 52-54; and Sheeran, Medieval Yorkshire Towns.

${ }^{39}$ Fenwick, Poll Taxes; and Glassock, Lay Subsidy.

${ }^{40}$ Allison, History; Baines, Baines's Yorkshire; Beresford, Lost Villages; Beresford and Hurst, Deserted Medieval Villages; Darby, New Historical Georgraphy; Fenwick, Poll Taxes; Hoskins, Local History; Langdale, Topographical Dictionary; Russell, Medieval British Population; Scholfield, "Georgaphical Distribution"; and Sharp, New Gazetteer.
} 
ernmental and economic units. Parish boundaries often outlined jurisdictions of local courts that enforced laws concerning the cultivation of open fields and distribution of customary poor support. Six hundred eighteen rural parishes existed. Substituting parishes for villages in equation 1 indicates that 1.26 fraternities operated in the typical parish in the typical year, or roughly five fraternities for every four parishes.

The second component of my estimate with an uncertain value is $A$, the longevity of the typical fraternity. The value that I employ in my estimate, 33.5 years, is the average length of time between the first and last observations for all fraternities with two or more observations. This average might be an underestimate of fraternal longevity, because the first and last observations are seldom the fraternities' inception and demise. This average might also be an overestimate, because multiple observations might exist for unusually large, successful, and long lasting fraternities. A statistical method called duration analysis helps to account for these possibilities. It also facilitates the inclusion of all observations in the analysis, including those with only one observation. Duration analysis yields an estimate of average longevity where the components of the average are weighted depending upon the characteristics of fraternities, the characteristics of villages, and assumptions employed in the analysis. Making all assumptions in a manner that minimizes the estimate-for instance, by assuming that fraternities with only one observation operated only on the date of observation and disbanded the day after-yields estimates of longevity as low as ten years but never below that amount. Making all assumptions in a manner that maximizes the estate yields estimates of longevity up to 65 years but never above that amount. Employing the minimum estimate in my calculations would lower the estimate of the number of fraternities by approximately two-thirds, to one fraternity in every four villages. Employing the upper bound would double the estimate, to three fraternities in every two villages.

The third variable with an uncertain value is $S$, the document survival or sampling rate. Estimates of that rate drawn from the corporate census, which are appropriate to use when examining Bainbridge's data set as a substantial share of its influential observations come from the census, are less applicable in this case, because census records survive in only miniscule quantities for York.

The bulk of Crouch's data comes from testamentary sources. Crouch describes his sampling process in detail.

The huge quantity of wills made, over the period . . . could only be sampled in the time available to me. The sources of the sample were limited to wills recorded in the probate registers of the Diocesean Exchequer Court, The Dean and Chapter's Court and the archbishops' registers, making use of the standard will 
indices. The total number of available wills relating to the historic county of Yorkshire, excluding York, is approximately fifteen thousand. The method of sampling chosen, of four years in every twelve throughout the period, yielded a total of 5,261 wills read. ${ }^{41}$

Crouch also notes that the wills that he samples are themselves a sample of bequests (and other records of deaths) once collected in the county of York. There are occasional chronological gaps and "significant geographical gaps in the records," and no records drawn from rural jurisdictions, such as manorial or hundred courts. ${ }^{42}$

Furthermore, "wills were made in significant quantities by a narrow band of the population that was wealthy enough to have sufficient possessions to bequeath. ${ }^{, 43}$ As average incomes rose, the share of the population writing wills also rose. Residents of rural villages began writing more than a modest number of wills only in the sixteenth century. Finally, only a fraction of guild members left bequests to their organization.

Clearly, bequests to guilds were made only by the wealthiest and most highly motivated members. ... Even the gild that received the most legacies in the entire area, that of Corpus Christi in York, received only 360 bequests from a total recorded membership of over $16,850 \ldots$ there is some evidence to suggest that the York Corpus Christi Gild offered superior funerals in return for bequests, indicating that the two percent of members that made bequests to it represents an atypically high feature. ${ }^{44}$

Combining Crouch's two pieces of quantitative information-he sampled one-third of all wills, and members mentioned fraternities in only one in 50 of wills - yields a sampling rate of one in 150 , or 0.66 percent. My calculation of equation 1 uses a more conservative approximation based on the following pieces of information. Crouch sampled one will in three. Because of chronological, geographic, and jurisdictional lacunae in the documents (and verified by comparisons to other counties via Gibson's handbook Wills and Where to Find Them), the wills that Crouch sampled represent roughly one-eighth of the wills once recorded in Yorkshire. I ignore the fact that only a small fraction of fraternity members wrote wills and the fact that only a fraction of the wills that were written contain bequests to particular fraternities. Multiplying one-third and one-eighth together and rounding up to the nearest

\footnotetext{
${ }^{41}$ Crouch, Piety, pp. 9-10.

${ }^{42}$ Crouch, Piety, p. 46.

${ }^{43}$ Crouch, Piety, pp. 46-47.

${ }^{44}$ Crouch, Piety, pp. 48.
} 
percent yields the 5 percent figure that I employ in my calculations. This sampling rate, I should stress, is a conservative figure. The true figure is almost certainly lower, perhaps as Crouch's analysis of the Corpus Christi guild suggests, by an order of magnitude. Thus, my estimate of approximately three-fourths of a fraternity per village is almost certainly an underestimate.

The corporate census of 1388 provides another approximation of the number of fraternities per village or parish. Almost all of the surviving returns come from a cluster of counties in eastern England. Those counties contained roughly 4,500 rural parishes. Two hundred thirty-four census returns survive from fraternities located in those communities. Dividing the number of returns by the number of places reveals that one return survives for roughly every 20 parishes. Assuming the document loss rate of rural fraternities equaled that of London's guilds, then approximately one fraternity existed in every other rural parish in 1388 . That assumption seems safe, since the loss rate for rural fraternities, almost certainly exceeded that of London guilds by a wide margin.

In sum, the data support Kimball's conjecture. At a bare minimum, the extant evidence indicates that one fraternity existed in every other village between the late fourteenth century and the early sixteenth century. This raw figure seems strikingly large. Only a fraction of farmers' cooperatives generated documents. The bulk of the documents that once existed disappeared over time. Only a fraction of the surviving sources have been studied by scholars. Most of the surviving documents have yet to be discovered. Given these facts, the conclusion of the experts on the issue - that fraternities existed in most and perhaps all villagesseems reasonable. It is certainly consistent with the evidence. McCloskey's claim that peasants never formed farmers' cooperatives is not.

\section{CUSTOMARY POOR LAWS}

Another institution existed in medieval English villages that fit Kimball's definition of farmer's cooperatives. It was called customary poor support. Customary poor laws permitted peasants in need to pick peas from any field in their village, even those owned by their neighbors, and to glean grain spilled during the harvest.

Rules regarding pea picking were straightforward. Peasants who owned arable land had to plant peas when the communal crop rotation required them to do so, and landowners could not pick other people's peas until they had consumed their own. Poor peasants could collect peas anywhere in the village as long as they gathered them during day- 
light and from the edge of a patch. A typical example comes from the manor of Newton Longville in Buckinghamshire, where in 1290, the manorial court declared that:

no one who holds land of the lord shall gather peas, beans, or vetches in the fields except on the land that they have sown . . . anyone who wants to gather beans, peas, or such like shall gather them between sunlight and prime in le Hech' [one of the fields], and this [may be done] after the Feast of the Blessed Virgin Mary [March 25] . . . no pauper be allowed to gather beans between the selions but only at the ends and the dividing lines. And if he shall do otherwise he shall lose what he has gathered and he shall not be allowed to enter the fields thenceforth to gather beans ... no one shall [gather] peas by night. ${ }^{45}$

Another example comes from the manor of Wimeswould in Leicestershire, where in 1425 , the manorial court reiterated the ancient custom that:

all manner of men that have any pease in the field when the coddling time comes, let them cod in their own lands and in no other man's lands. And other men or women that have no peas of their own growing, let them gather twice in the week on Wednesday and on Friday, reasonably going in the land-furrows and gathering with their hands and with no sickles, once before noon and no more, for if any man or woman other that has any peas of his own and goes into any other, for each time [he shall] pay a penny to the church and lose his cods, and they that have none and go oftener than it is before said, with sickle or without, shall lose the vessel they gather them in and the cods, and a penny to the church. $^{46}$

As these examples illustrate, coddling customs minimized pea picking's impact on village agriculture. The customs prevented people from coddling wastefully or trespassing in the open fields.

Similar emphasis appears in rules regarding gleaning. A typical ordinance comes from the manor of Welwyn Rectory in Hertfordshire, where in 1287 , the manorial court declared:

men and women who are able to reap be distrained not to glean in the fashion of paupers and that those who harbour them be punished and whatever the gleaners have gathered be seized. ${ }^{47}$

This rule restricted gleaning to paupers who needed to glean the most, and ensured that gleaning opportunities did not reduce the supply of harvest time labor.

\footnotetext{
${ }^{45}$ Ault, Open-Field Farming, pp. 38-40, 82-83.

${ }^{46}$ Fisher and Jurica, Documents, p. 115.

${ }^{47}$ Ault, Open-Field Farming, pp. 19, 27-34, 82, 91.
} 
These customs pooled the risk of crop failure among village residents, and did so effectively and efficiently, because they provided maximum nutrition at minimum cost. On that point, the evidence is clear. Consider pea picking. Peas provided more nutrients and calories per pence than any other crop. Peas' kilocalorie extraction rate was nearly 100 percent, and peas cost four pence per bushel. In contrast, bread grains' kilocalorie extraction rate was 80 percent. Brewing grains kilocalorie extraction rate was 30 percent. Bread grains cost nine pence per bushel, and brewing grains cost 6.5 pence per bushel. ${ }^{48}$ Peas also replenished soil fertility. So, prosperous peasants had an incentive to plant legumes even if they donated the harvest to needy neighbors. Now consider gleaning. For gleaned grain, the number of calories per pence was also high. Gleaning yielded several pounds of grain per acre because medieval reaping methods dislodged substantial quantities of ripe kernels. That grain contained many calories, but had little market value, as gleaned grain was dirty and damp and therefore could neither be stored until the spring nor sold for significant sums.

In addition to maximizing calories and minimizing costs, the combination of picking peas and gleaning grain had two additional advantages. First, the combination fed the poor year round, because coddling (i.e., pea picking) and gleaning had complementary calendars. Coddling occurred during the spring and summer, and the proceeds were consumed at that time, because green peas were highly nutritious. Grain was not eaten during the growing season, because unripe grain was not nutritious. Gleaning occurred in the fall following the harvest. Gleaned grain was edible during the fall and winter. Second, the combination of gleaning and coddling minimized the incentive to exploit the system. Picked peas and gleaned grain made unappealing cuisine. To maximize caloric content, both had to be consumed as porridge. Plain porridge was a gooey gruel that tasted bland at best. No one wanted to eat plain porridge day after day. Thus, no one wanted to subsist on coddling and gleaning.

Enough evidence exists to corroborate these claims. Manorial court rolls often discuss customary poor laws and the penalties imposed on people for violating them. Scholars have found examples in dozens of

\footnotetext{
${ }^{48}$ For a discussion of kilocalorie extraction rates, see Campbell, "Matching Supply," p. 12. Kilocalorie extraction rates indicate the calories remaining after crops have been processed into their final form. The rates for bread and brewing grains have the following interpretation. Milling and baking consumed 20 percent of the calories in bread grains, while malting and brewing consumed 70 percent of the calories in beer grains. For grain prices, see Dyer, Standards of Living, p. 113, table 7.
} 
instances. ${ }^{49}$ As of yet, however, no scholar has assembled a data set that allows the prevalence of customary poor laws to be determined or that allows the prevalence of coddling and gleaning to be compared to the prevalence of other activities.

Several others are known to have existed. One village allowed needy residents to graze more than their share of animals on the commons. The normal share was proportional to an individual's holdings in the arable fields, but men whose harvests had failed and who lacked fodder were allowed to keep their animals alive at their neighbors' expense. Another custom, known to have existed on several Cambridgeshire manors, settled able-bodied poor men on small dower plots of land on the holdings of other men, usually relatives. This method "made a strong attempt to remove the root cause of poverty and establish a poor man in a position of self-respecting, though only partial, independence with the stimulus to make some effort for his own support. ${ }^{50}$ In this area, more research is needed, though there seems to be little doubt that such research will strengthen this section's conclusion by revealing additional evidence of customary poor laws in medieval English villages.

In sum, customary poor laws were effective and efficient solutions to the problems facing medieval peasants. They transferred enough food to keep individuals alive and did so at the least possible cost. Gleaned grain and picked peas could not be sold for significant sums, could be collected at low cost, and were unappetizing enough that people would work diligently to avoid eating them.

\section{DISCUSSION}

McCloskey's presumption that peasants neither pooled risk nor helped neighbors in need is clearly inconsistent with the evidence, whereas Kimball's claims are consistent with the data. His conjecture is confirmed. Farmers' cooperatives existed in medieval English villages, just as they operate in villages throughout the developing world today. Peasants pooled risk by forming risk-sharing cum religious societies and enacting customary poor laws. They imbedded both of these institutions within the framework of their communities. Courts, which enforced criminal and civil codes as well as rules regarding the holding of land and the collective cultivation of open fields, also enforced customary poor laws. Fraternities, which facilitated passage through purgatory,

\footnotetext{
${ }^{49}$ Ault, Open-Field Farming; DeWindt, Court Rolls; and Fisher and Jurica, Documents.

${ }^{50}$ Page, "Customary Poor Law," p. 133
} 
also helped peasants beset by hard times. Neither of these institutions was perfect. Fraternities drew members from the ranks of diligent and prosperous peasants, but neglected those who did not belong to their organizations. Customary poor laws helped paupers keep flesh on their bones, but transferred nowhere near enough income to entirely alleviate poverty. But, the combination protected most villagers from the idiosyncratic shocks that occasionally afflicted the farm fields of medieval England.

Exactly how many farmers' cooperatives existed is unknown. Lacunae exist in the evidence. But, it is safe to say that fraternities were widespread. At a minimum, they existed in one-in-ten villages in the open-field agricultural areas of eastern England in 1388, in one-of-two villages in Cambridgeshire between the Black Death and the Reformation, and in three-of-four villages in Yorkshire during that time period. The data substantiating those statements is a sample, probably small, of the data that once existed. So, it seems likely that fraternities existed in most villages during most of the period in question, and possible that farmers' cooperatives were ubiquitous, as the historians who study those institutions conclude and as Kimball conjectured.

It seems reasonable to conclude, therefore, that fraternities were a common method of mitigating the risks of everyday agrarian life. Other means of mitigating risk almost certainly existed. Recent research indicates that the storage of grain was an effective method of smoothing both idiosyncratic and aggregate shocks to the yields of grain growing fields. ${ }^{51}$ The diversification of crops significantly reduced the variability of yields in grain growing fields. ${ }^{52}$ Land, labor, commodity, and credit markets existed in all but the most remote villages and became increasingly liquid over time. These venues allowed peasants to pursue exchange-oriented survival strategies such as accumulating assets, substituting labor for leisure, and substituting consumption tomorrow for consumption today. ${ }^{53}$

Although this recent research contradicts McCloskey's claims concerning medieval agriculture, it is consistent with the Coasian logic underlying her model. Coase showed that inefficiencies persist only if missing or prohibitively expensive markets prevent people from rearranging their activities and alleviating the inefficiency. McCloskey combined that logic and the notion that markets did not exist in medieval England - which was the conventional academic wisdom 30 years

\footnotetext{
${ }^{51}$ Richardson, "What Protected Peasants."

${ }^{52}$ Cull, Hoffman, and Hughson, "New Evidence."

${ }^{53}$ Richardson, "What Protected Peasants."
} 
ago when she wrote the first of her series of seminal essays - and concluded that open-field agricultural operated inefficiently-which was also the conventional academic wisdom at the time. Recent research has overturned those previously popular views and shown that open fields grew grain efficiently. ${ }^{54}$ Markets for land and grain were ubiquitous. These new facts fit the Coase theorem as comfortably as the old facts but with the inverse implication. Inefficient grain-growing arrangements could not have persisted in medieval England, because extensive markets, stable institutions, and high volumes of transactions enabled peasants to rearrange activities and alleviate inefficiencies.

\footnotetext{
${ }^{54}$ Allen and Ó Gráda, "On the Road"; Campbell, "Matching Supply”; and Clark, "Commons Sense.”
}

\section{REFERENCES}

Allen, Robert C.. and Cormac Ó Gráda. "On the Road Again with Arthur Young: English, Irish, and French Agriculture During the Industrial Revolution.” This JOURNAL 48, no. 1 (March 1988): 93-116.

Allison, Keith. A History of the County of York, East Riding. 7 vols. The Victoria Histories of the Counties of England. Oxford: Oxford University Press, 1969.

Ault, W. O. Open-Field Farming in Medieval England: A Study of Village By-Laws. London: University of London Press, 1972.

Bainbridge, Virginia. Gilds in the Medieval Countryside: Social and Religious Change in Cambridgeshire, c. 1350-1558. Studies in the History of Medieval Religion, vol. 10. Rochester, NY: Boydell Press, 1996.

Baines, Edward. Baines's Yorkshire, a new printing of the two volumes of History, Directory and Gazetteer of the County of York. New York: Augustus M. Kelley, 1969.

Beresford, Maurice. The Lost Villages of England. Stroud, Gloucestershire: Sutton Publishing, 1998.

Beresford, Maurice, and John Hurst. Deserted Medieval Villages. London: Lutterworth Press, 1971.

Britton, Edward. The Community of the Vill: A study in the history of family and village life in fourteenth-century England. New York: Macmillan 1977.

Campbell, Bruce M. S. "Matching Supply to Demand: Agricultural Production and Disposal By English Demesnes in the Century of the Black Death." Paper presented at the annual conference of the Economic History Association, September 1996.

Cawley, A. C. Everyman and Medieval Miracle Plays. Rutland, VT: C. Tuttle, 1993.

Clark, Gregory. "Commons Sense: Common Property Rights, Efficiency, and Institutional Change." This JouRnal 58, no. 1 (March 1998): 73-102.

Crouch, David J. F. Piety, Fraternity, and Power: Religious Gilds in Late Medieval Yorkshire, 1389-1547. Rochester, NY: York Medieval Press, 2000.

. Gazetteer of the Religious Gilds and Services of Late Medieval Yorkshire. University of York, Centre for Medieval Studies Web Site. http://www.york.ac.uk/inst/cms/resources/gilds. 2002

Cull, Robert J., Philip T. Hoffman, and Eric Hughson. "New Evidence for an Old 
Controversy: Scattered Landholdings and Open Fields." Caltech Working Papers in Social Science \# 788, February 1992.

Darby, Henry Clifford. A New Historical Geography of England. Cambridge: Cambridge University Press, 1973.

DeWindt, Edwin Brezette. Land and People in Holywell-cum-Needingworth: Structures of Tenure and Patterns of Social Organization in and East Midlands Village. 1252-1457. Pontifical Institute of Mediaeval Studies, Studies and texts, 22. Toronto, Canada: Pontifical Institute of Mediaeval Studies, 1972.

. The Court Rolls of Ramsey, Hepmangrove, and Bury, 1268-1600. Toronto: Pontifical Institute of Medieval Studies, 1990.

Duparc, P. "Confraternities of the Holy Spirit and Village Communities in the Middle Ages." in Lordship and Community in Medieval Europe, edited by F. L. Cheyette. New York: Holt, Rinehart, and Winston, 1975.

Dyer, Christopher. Standards of Living in the later Middle Ages: Social Change in England c. 1200-1520. Cambridge: Cambridge University Press, 1994.

Fenwick, Carolyn C. The Poll Taxes of 1377, 1379 and 1381: Part 1, BedfordshireLeicestershire. Oxford: Oxford University Press, 1998

Fisher, H. E. S., and A. R. J. Jurica. Documents in English Economic History: England from 1000 to 1760. London: G. Bell and Sons Ltd, 1977.

Glassock, Robin. The Lay Subsidy of 1334. Oxford: Oxford University Press, 1975.

Hanawalt, Barbara. The Ties That Bound: Peasant Families in Medieval England. Oxford: Oxford University Press 1986.

"Keepers of the Lights: Late Medieval English Parish Gilds." Journal of Medieval and Renaissance Studies 14 (1984): 21-37.

Harper-Bill, Christopher. The Pre-Reformation Church in England: 1400-1530. New York: Longman 1989.

Harvey, Barbara. Living and Dying in England, 1100-1540, The Monastic Experience. Oxford: Oxford University Press 1995.

Hoskins, W. G. Local History in England. London: Longmans, 1959.

Hunt, T. J., ed. Medieval Customs of the Manors of Taunton and Bradford on Tone. Somerset Record Society Publications, vol. 66. Frome, UK: Butler \& Tanner, 1962.

Jones, W. R. "English Religious Brotherhoods and Medieval Lay Piety: The Inquiry of 1388-9." The Historian 36 (1974): 646-59.

Kimball, Miles. "Farmers' Cooperatives as Behavior Toward Risk." American Economic Review 78, no. 1 (March 1988): 224-32.

Langdale, Thomas. A Topographical Dictionary of Yorkshire, Second Edition. Northallerton, UK: J. Langdale, 1822.

Langland, William. Piers Plowman: A New Translation of the B-Text. Translated by A. V. C. Schmidt. Oxford: Oxford University Press, 1992.

Mattingley, H. "The Medieval Parish Guilds of Cornwall." Journal of the Royal Institution of Cornwall, new series x, 1989, pp. 290-329.

McCloskey, Donald. "English Open Fields as Behavior Towards Risk." Research in Economic History 1 (Fall 1976): 124-70.

"The Prudent Peasant: New Findings on Open Fields." This Journal 51, no. 2 (June 1991): 343-55.

McLaughlin, Mary, and James Ross. The Portable Medieval Reader. New York: Penguin Books, 1977.

Mollat, Michel. The Poor in the Middle Ages: An Essay in Social History. Translated by Arthur Goldhammer. New Haven, CT: Yale University Press, 1986. 
Page, F. M. "The Customary Poor-Law of Three Cambridgeshire Manors." Cambridge Historical Journal (1930): 125-33.

Palmer, W. M. "Village Gilds of Cambridgeshire." Cambridgeshire and Huntingdonshire Archeological Society (1902): 330-402.

Public Record Office, Guild Returns from 1388, (C47/38-46).

Raftis, J. A. "Social Structures in Five East Midland Villages: A Study in the Use of Court Roll Data." Economic History Review 18 (1965): 83-100.

Richardson, Gary. "What Protected Peasants Best? Markets, Risk, Efficiency, and Medieval English Agriculture." Research in Economic History, 2003.

Rosser, Gervase. "Communities of Parish and Guild in the Late Middle Ages." In Parish Church and People: Local Studies in Lay Religion 1350-1750, edited by S. Wright, 29-55. London: Hutchinson, 1988.

. "Going to the Fraternity Feast: Commensiality and Social Relations in Late Medieval England.” Journal of British Studies 33 (October 1994): 430-46.

Rubin, Miri. Charity and Community in Medieval Cambridge. Cambridge: Cambridge University Press, 1987.

Russell, Josiah Cox. British Medieval Population. Albuquerque, NM: University of New Mexico Press, 1948.

Scholfield, R. S. "The Geographic Distribution of Wealth in England 1334-1649." Economic History Review 18 (1965): 483-510.

Sharp, James. A New Gazetteer or Topographical Dictionary of the British Islands. London: Brown, Green, and Longmans, 1852.

Sheeran, George. Medieval Yorkshire Towns: People, Buildings, and Spaces. Edinburgh: Edinburgh University Press, 1998.

Smith, Toulmin. English Gilds: The Original Ordinances of more than one hundred Early English Gilds. London: Early English Text Society, 1870.

Thrupp, Sylvia. The Merchant Class of Medieval London, 1300-1500. Chicago: University of Chicago Press, 1948.

Tierney, Brian. Medieval Poor Law: A Sketch of Canonical Theory and Its Application in England. Berkeley: University of California Press, 1959.

Titow, J. Z. English Rural Society, 1200-1350. London: Allen and Unwin, 1969.

Tuck, J. A. "The Cambridge Parliament, 1388." The English Historical Review 84, no. 331 (April 1969): 225-43.

Unwin, George. The Gilds and Companies of London. London: F. Cass, 1963.

Westlake, H. F. The Parish Gilds of Medieval England. London: Society for Promoting Christian Knowledge, 1919. 